\title{
Göller Bölgesi İllerinde Yetiştirilen Nohut Genotiplerinin Bazı Kalite ve Teknolojik Özellikleri Yönünden Değerlendirilmesi
}

\author{
*Muharrem KAYA Ruziye KARAMAN Murat ÇAPAR
}

Süleyman Demirel Üniversitesi, Ziraat Fakültesi, Tarla Bitkileri Bölümü, Isparta

*Sorumlu yazar e-posta (Corresponding author e-mail): muharremkaya@sdu.edu.tr

\section{Öz}

Araştırma; Göller Bölgesinde yer alan illerden toplanan yerel nohut populasyonları ile yörede yetiştirilen tescilli nohut çeşitlerinin tane ve bazı teknolojik özelliklerinin belirlenmesi amacıyla 2013-2014 yıllarında SDÜ Ziraat Fakültesi Tarla Bitkileri laboratuarlarında yürütülmüştür. Isparta, Burdur, Denizli, Uşak ve Afyonkarahisar illerinde nohut tarımının yoğun yapıldığı ilçe ve köylerde, üretici tarlalarından farklı nohut genotipleri ile en fazla yetiştirilen tescilli çeşitlerin tohumları toplanmış, ebatlarına ve kabuk renklerine göre gruplandırılmıştır. Denemede, elde edilen tohumlarda; kabuk oranı, 100 tane ağırığı, elek analizi, tane nem içeriği, kuru ağırlık, yaş ağırlık, su alma kapasitesi ve indeksi, kuru hacim, ıslak hacim, şişme kapasitesi ve indeksi, pişme süresi ve ham protein oranı özellikleri 3 tekrarlamalı olarak belirlenmiştir. Elde edilen verilerle Tesadüf Parselleri Deneme desenine göre varyans analizi yapılmış ve ortalamalar Tukey testi ile kıyaslanmıştır. Araştırma sonuçlarına göre; kuru ağırlık 32.27-60.49 g; yaş ağılık 72.06-132.82 g; kuru hacim 27.33-49.66 ml; ıslak hacim 55.33-109.33 ml; ham protein oranı \%18.24-27.57; pişme süresi 30-90 dakika; 100 tane ağırlığı 34.79$64.99 \mathrm{~g}$; kabuk oranı \%0.66-3.07; su alma kapasitesi 0.39-0.72 g/tane; su alma indeksi 0.7-3.46; şişme kapasitesi 0.253-1.153 g/tane; şişme indeksi 1.847-3.633 ve tane nem içeriği ise \%3.88-12.27 arasında değişmiş olup, denemede kullanılan tohumların \%35.15’i 31 kalibre ve üzeri irilikte olduğu belirlenmiştir.

Anahtar Kelimeler: Nohut, kalite, teknolojik özellikler

\section{Evaluation for Some Quality and Technological Properties of Grown Chickpea Genotypes in the Lake District Provincials}

\begin{abstract}
Research was conducted grain and some technological properties of local chickpea populations collected from provinces near and located in the Lake District with registered chickpea varieties grown in the region at SDU Faculty of Agriculture Field Crops Laboratories in 2013-2014. Different chickpea genotypes with the most grown registered varieties seeds were collected and classified according to size and colour of testa from producer field sin provinces of Isparta, Burdur, Denizli, Uşak ve Afyonkarahisar of villages and towns where chickpea cultivation done intensely. In experiment, in obtained seeds; properties of testa rate, 100 grain weight, sieve analysis, content of moisture grain, dry weight, wet weight, capacity of water in take and index, dry volume, wet volume, swelling capacity and index, cooking time and crude protein rate is determinated as three replications. It was made analysis of variance according to Completely Randomized Parcel Design with obtained data and averages was compared with test of Tukey. According to results; among dry weight 32.27-60.49 g; wet weight 72.06-132.82 g; dry volume 27.33-49.66 ml; wet volume 55.33-109.33 $\mathrm{ml}$; crude protein rate 18.24-27.57\%; cooking time 30-90 minutes; 100 grain weight 34.79-64.99 g; testa rate 0.66-3.07\%; capacity of water in take $0.39-0.72$ g/grain; water in take index $0.7-3.46$; swelling capacity $0.253-$ $1.153 \mathrm{~g} /$ grain; swelling index $1.847-3.633$ and content of moisture grain $3.88-12.27 \%$ have changed. It is determinated as seeds in using experiment $35.15 \%$ are 31 calibre and upper size.
\end{abstract}

Keywords: Chickpea, quality, technological properties

\section{Giriş}

$\mathrm{N}$ ohutun kimyasal bileşimi ve teknolojik özellikleri yetişme yerinin ekolojik koşulları, çeşidin genotipine ve yetiştirme tekniklerine bağlı olarak büyük farklılıklar göstermektedir. Nohutta tane protein oranı diğer baklagillere göre kısmen düşük olmakla birlikte; nohut proteinindeki amino asitler incelendiğinde çok kaliteli bir besin olduğu anlaşılmaktadır. Vejetasyon süresi boyunca nohut tanelerindeki amino asit kompozisyonu değişmektedir. 
Nitekim gelişmenin ilk devrelerinde tanede lisin ve threonin amino asitleri yüksek iken, olgunluk döneminde bu amino asitlerin miktarı azalmakta, diğer esansiyel amino asit miktarları artmaktadır. Tane rengi, tohum iriliği gibi faktörlerde nohutun tercih edilmesini etkilemektedir. Nohutta tane rengi beyazdan siyaha kadar ve tane iriliği de (100 tane ağırlığı 64-650 g) büyük varyasyon göstermekte ve nohutta renk ve irilik teknolojik özellikleri etkilemektedir. Gerek nohut üreticileri gerekse tüketiciler yaygın olarak alışmış oldukları yerel çeşitleri tercih etmektedirler. Kimi üretici ve tüketicilerin ise yeni çeşitlerin özellikle teknolojik özelliklerinden haberi yoktur. Nitekim, sertifikalı tohumluk kullanımına önemli prim destekleri verilmesine karşın hala sertifikalı nohut çeşitlerinin tohumluklarının yeterli düzeyde olduğu söylenemez. Bu nedenle tescilli nohut çeşitleri ile yerel nohut çeşitlerinin bazı kalite ve teknolojik özelliklerinin kıyaslanmasında büyük yararlar bulunmaktadır. Ayrıca üreticilerin yaygın olarak kullandıkları yerel populasyonların bazı tarımsal ve teknolojik özellikleri yönünden üstün özelliklerinin belirlenmesi nohut ıslahçılarının çalışmalarında materyal olarak ta kullanılabilecektir (Cengiz 2007).

Karasu (1993), bazı nohut çeşitlerinin agronomik ve teknolojik karakterleri ile ilgili çalışmasında, genel olarak 100 tane ağırlığı ile su alma kapasitesi arasında olumlu, protein oranı ile pişme süresi ve su indeksi arasında olumsuz ve önemli, protein oranı ile şişme kapasitesi arasında olumlu ve önemli ilişki saptamıştır. Yağ oranı ile pişme süresi, şişme kapasitesi arasında olumlu ve önemli, pişme süresi, su alma kapasitesi ve su alma indeksi arasında olumlu ve önemli ilişkiler tespit etmiştir.

Ercan ve ark. (1995), Türkiye'de yetiştirilen nohut çeşitlerinin pişme kalitesi ve kompozisyonu ile ilgili çalışmalarında kalite kriterleri olarak nohutların kuru ve ıslak tohum ağırlıkları, hacimleri, hidratasyon kapasiteleri ve indeksleri, su alma kapasiteleri ve indeksleri, kuru ve ıslak pişme zamanları esas alınmıştır. Yapılan çalışma sonucunda kalite kriterlerinin bazıları (su alma ve hidratasyon indeksi, kuru ve ıslak pişme zamanı) ve $\mathrm{K}, \mathrm{Ca}, \mathrm{Mg}, \mathrm{Na}$ ve riboflavin içeriklerinin aslında genotip tarafından etkilendiği tespit edilmiştir. Kuru ve ıslak ağırlık, kuru ve Islak hacim, hidratasyon kapasitesi, şişme kapasitesi ve $\mathrm{Cu}, \mathrm{Zn}$ ve thiamin içeriği için farklıığın başlıca kaynağının lokasyon (yetiştirme yeri) olduğu belirtilmiştir.
Akdağ (1996), yemeklik tane baklagillerde en önemli kalite özelliklerinden birisi de pişme durumudur. Tanenin pişme süresini genetik yapı yanında yetişme şartları da önemli ölçüde etkilemektedir. Tane kabuğunun kalınlığı ve kimyasal bilesimi pişme süresini önemli ölçüde etkiler. Kabukta palizat hücreleri kalınlığı, pektin, lignin, $\mathrm{Ca}$ ve $\mathrm{Mg}$ miktarları arttıkça tanenin su alımı engellenerek pişme süresi uzamaktadır. Ayrıca erken hasat, $\mathrm{Ca}$ ve $\mathrm{Mg}$ miktarları yüksek topraklarda yetiştirmek, uygun olmayan (\%13-14 nem ve $10^{\circ} \mathrm{C}$ depo sıcaklığı düzeylerinden daha yüksek) şartlarda uzun süre depolamak gibi faktörler de yemeklik baklagil tanelerinde pişme kalitesini olumsuz etkilemektedir.

Wiryaman (1997), baklagil tohumlarının protein içeriklerinin türler içinde ve cinsler arasında \%20-38 arasında olduğunu belirterek, yaptığı çalışma sonucunda baklagillerin kuru madde içeriklerinin çok fazla değişim göstermediğini, incelenen 10 adet baklagil numunesinin ortalama kuru maddesini $90.07 \pm 9.5 \mathrm{mg} / \mathrm{g}$ olarak bildirmiştir. Ayrıca kuru fasulyenin besinsel kompozisyonunu ham protein $240 \mathrm{~g} / \mathrm{kg}$, ham yağ $20 \mathrm{~g} / \mathrm{kg}$, ham lif 40 $\mathrm{g} / \mathrm{kg}$, ham kül $40 \mathrm{~g} / \mathrm{kg}$, kalsiyum $2.5 \mathrm{~g} / \mathrm{kg}$, fosfor $4.0 \mathrm{~g} / \mathrm{kg}$ olarak belirlemiştir.

Jood et al. (1998), nohut ve mercimekte kimyasal ve fizikokimyasal analizler ile ilgili bir çalışmasında, nohut da şişme indeksini \%1.822.27, şişme kapasitesini 0.094-0.255 ml/tane aralıklarında tespit etmiştir.

Bu çalışmada amacımız, Göller Bölgesi ve yakınlarında yer alan illerden (Isparta, Burdur, Denizli, Uşak, Afyonkarahisar) toplanan yerel nohut populasyonları ve tescilli nohut çeşitlerinin protein oranı, kabuk oranı ve bazı teknolojik özellikler (100 tane ağırlığı, tane nem oranı, kuru ağırlık, yaş ağırlık, su alma kapasitesi ve indeksi, kuru hacim, Islak hacim, şişme kapasitesi ve indeksi, protein oranı ve pişme süresi) yönünden kıyaslamaya çalışmaktır.

\section{Materyal ve Yöntem}

Çalışmada; Göller Bölgesi ve yakınlarda yer alan Isparta, Burdur, Denizli, Uşak, Afyonkarahisar illerinde, yerel nohut çeşitleri nohut tarımının en fazla yapıldığı köylerden üreticilerden direkt olarak ya da bu çeşitlerin ticaretini yapan işletmelerden toplanmıştır. Her genotipin mümkün olduğunca orijin özellikleri ve lokasyonun koordinatları kaydedilmiştir. Survey 
çalışmaları sonunda 65 materyal toplanmıştır. Bunların bir kısmı ticari değeri olmadığından elenmiştir. Kalan örnekler tohumların morfolojik özellikleri ve toplanma bölgeleri de dikkate alınarak birbirine benzer olanlar birleştirilmiş ve toplam 18 genotipe düşürülmüştür. Yöresel olarak verilen isimlerine ya da toplandığı köye göre isimlendirme yapılmıştır. Kontrol amaçlı olarak ta Tarla Bitkileri Merkez Araş. Enstitüsünden elde edilen ve bölümümüzde denemeleri yapılan Çakır, Hisar, Sarı 98 ve Uzunlu 99 çeşitleri materyal olarak kullanılmıştır. Denemede; yemeklik tane baklagiller teknolojik değerleri belirleme teknik talimatına göre, aşağıdaki gözlem ve ölçümler 3 tekrarlamalı olarak yapılmıştır.

Çalışmada; nohutta 100 tane ağırlığı (g), tane nem içeriği (\%), kuru ağırlık(g), yaş ağırlık (g), su alma kapasitesi (g/tane), su alma indeksi, kuru hacim $(\mathrm{ml})$, Islak hacim $(\mathrm{ml})$, şişme kapasitesi, şişme ındeksi, protein oranı (\%), kabuk oranı (\%), pişme süresi (dak), ve elek analizi $(\mathrm{mm})$ özellikleri incelenmiştir.

Deneme sonunda elde edilen verilerle, tesadüf parselleri deneme desenine göre varyans analizi yapılmış ve farklılıkların önem düzeyleri Duncan testine göre belirlenmiştir.

\section{Bulgular ve Tartışma}

Çalışmada, nohut genotiplerinde kuru ağırlık, yaş ağırlık, kuru ve ıslak hacim, protein oranı, pişme süresi, 100 tane ağırlığı, kabuk oranı, su alma kapasitesi, su alma indeksi, şişme kapasitesi, şişme indeksi, nem oranı özelliklerine ilişkin elde edilen verilerle yapılan varyans analizi sonunda ele alınan tüm özelliklerde genotipler arasındaki farklılıklar 0.01 düzeyinde önemli bulunmuştur. Genotipler arasındaki farklılıklar ise 0.05 hassasiyet ile Duncan testine göre gruplandırılmıştır. Elde edilen ortalamalar aşağıda ayrı çizelgelerde özetlenmiştir.

Denemede kullanılan tüm çeşitler elek analizlerine göre sınıflandırılmış ve her elek grubuna giren tane oranları Çizelge 4'te verilmiştir.

Çizelge 1'de görüldüğü gibi, nohut genotipleri arasında kuru ağırlık ortalamaları bakımından yüksek oranda varyasyonlar belirlenmiş olup, en yüksek kuru ağırık ortalamaları Kabak, Gelendost ve Yeşilköy genotiplerinde, en düşük kuru ağırlık değerleri ise Ağlasun, Ziraat2, Leblebilik ve Uzunlu 99 nohut genotiplerinde belirlenmiştir. Yaş ağırlık ortalamalarında da kuru ağırlığa benzer şekilde sonuçlar elde edilmiş, en yüksek ortalamalara Kabak, Gelendost ve

Çizelge 1. Göller yöresi illerinden toplanan bazı nohut genotiplerinde kuru ağırlık (KA), yaş ağırlık (YA), kuru hacim $(\mathrm{KH})$ ve ıslak hacim $(\mathrm{IH})$ ortalamaları*

Table 1. Dry weight (KA), wet weight (YA), dry volume $(K H)$ and wet volume $(I H)$ averages of some chickpea genotypes collected from the Lake District Provincials

\begin{tabular}{lcccc}
\hline Çeşitler & $\mathrm{K} \mathrm{A}$ & $\mathrm{YA}$ & $\mathrm{KH}$ & $\mathrm{IH}$ \\
\hline Kırmızı yerel & $42.32 \mathrm{I}$ & $95.11 \mathrm{~g}$ & $36.00 \mathrm{e}$ & $86.00 \mathrm{~g}$ \\
Ağlasun & $32.27 \mathrm{u}$ & $72.06 \mathrm{n}$ & $27.33 \mathrm{k}$ & $62.33 \mathrm{I}$ \\
Çetince & $35.90 \mathrm{q}$ & $77.82 \mathrm{l}$ & $30.00 \mathrm{j}$ & $55.33 \mathrm{~m}$ \\
Uzunlu 99 & $35.07 \mathrm{r}$ & $80.81 \mathrm{k}$ & $31.66 \mathrm{hı}$ & $70.33 \mathrm{jk}$ \\
Çaltı & $42.62 \mathrm{~h}$ & $92.78 \mathrm{~h}$ & $34.33 \mathrm{efg}$ & $82.00 \mathrm{~h}$ \\
Ziraat1 & $45.35 \mathrm{e}$ & $108.48 \mathrm{~d}$ & $41.33 \mathrm{c}$ & $93.33 \mathrm{f}$ \\
Karamanlı & $39.45 \mathrm{k}$ & $90.17 \mathrm{I}$ & $33.66 \mathrm{~g}$ & $81.66 \mathrm{~h}$ \\
A. Gökdere & $43.73 \mathrm{f}$ & $97.36 \mathrm{f}$ & $39.33 \mathrm{~d}$ & $98.33 \mathrm{~d}$ \\
Çakır & $43.42 \mathrm{~g}$ & $92.25 \mathrm{~h}$ & $35.33 \mathrm{ef}$ & $98.66 \mathrm{~d}$ \\
Yarıkkaya & $38.69 \mathrm{l}$ & $89.79 \mathrm{I}$ & $34.66 \mathrm{efg}$ & $81.66 \mathrm{~h}$ \\
Körküler & $41.04 \mathrm{j}$ & $93.38 \mathrm{~h}$ & $36.00 \mathrm{e}$ & $84.33 \mathrm{~g}$ \\
Hisar & $36.32 \mathrm{p}$ & $80.86 \mathrm{p}$ & $33.33 \mathrm{gh}$ & $69.66 \mathrm{k}$ \\
İspanyol & $37.39 \mathrm{n}$ & $81.26 \mathrm{n}$ & $33.66 \mathrm{~g}$ & $71.66 \mathrm{j}$ \\
Denizli & $37.02 \mathrm{o}$ & $81.03 \mathrm{o}$ & $31.66 \mathrm{I}$ & $69.66 \mathrm{k}$ \\
Bozkır & $42.74 \mathrm{~h}$ & $110.48 \mathrm{~h}$ & $41.00 \mathrm{~cd}$ & $99.00 \mathrm{~d}$ \\
Gelendost & $49.43 \mathrm{~b}$ & $115.75 \mathrm{~b}$ & $45.33 \mathrm{~b}$ & $102.33 \mathrm{c}$ \\
Yeşilköy & $49.17 \mathrm{c}$ & $115.32 \mathrm{c}$ & $44.66 \mathrm{~b}$ & $103.33 \mathrm{bc}$ \\
Kabak & $60.49 \mathrm{a}$ & $132.82 \mathrm{a}$ & $49.66 \mathrm{a}$ & $109.33 \mathrm{a}$ \\
Sarı 98 & $45.76 \mathrm{~d}$ & $99.14 \mathrm{~d}$ & $40.66 \mathrm{~cd}$ & $104.66 \mathrm{~b}$ \\
Leblebilik & $33.35 \mathrm{~s}$ & $79.11 \mathrm{~s}$ & $30.00 \mathrm{j}$ & $95.33 \mathrm{e}$ \\
Ziraat2 & $33.16 \mathrm{t}$ & $75.26 \mathrm{t}$ & $28.66 \mathrm{jk}$ & $72.33 \mathrm{I}$ \\
Ziraat3 & $38.10 \mathrm{~m}$ & $84.81 \mathrm{~m}$ & $33.66 \mathrm{fg}$ & $95.33 \mathrm{e}$ \\
\hline Ortalama & 41.03 & 92.99 & 35.99 & 81.09 \\
\hline * Aynı harfle gösterilen ortalamalar arasında farklılık yoktur & & \\
*Averages followed by same letter are not different & & & \\
& & & &
\end{tabular}


Yeşilköy genotipleri sahip olmuştur. En düşük yaş ağırlık değerleri ise Ağlasun, Ziraat2, Çetince ve Leblebilik nohut genotiplerinde görülmüştür. Çeşitlerin genel ortalaması olarak; kuru ağırlık $41.03 \mathrm{~g}$; yaş ağırlık ise $92.99 \mathrm{~g}$ olarak hesaplanmıştır. Nohut çeşitlerinde kuru ve ıslak hacim bakımından da önemli farklılıklar belirlenmiş olup, genellikle kuru ve ıslak hacim yönünden çeşitlerin tepkileri benzer olmuştur.

En yüksek kuru hacim ortalamaları Kabak, Yeşilköy, Gelendost, Ziraat1 ve Sarı 98 çeşitlerinde belirlenmiştir.

En yüksek ıslak hacim ortalamaları ise Kabak, Yeşilköy, Gelendost ve Sarı 98 çeşitlerinde gözlenmiştir (Çizelge 1). En düşük kuru hacim Ağlasun ve Ziraat 2 çeşitlerinde; en düşük ıslak hacim ise Çetince genotipinde belirlenmiştir.

Çizelge 2'nin de incelenmesinden anlaşılacağı gibi, çeşitlerin ortalaması olarak protein oranı \%21.5 olarak hesaplanmış olup, en yüksek protein oranı ortalamaları Ziraat2, Uzunlu 99, Bozkır ve A. Gökdere genotiplerinde, en düşük protein oranı ise Ağlasun, Kırmızı yerel ve Çetince nohut genotiplerinde saptanmıştır. Pişme süreleri ortalamalarında da önemli varyasyonlar gözlenmiş olup, en kısa pişme süresi değerleri Gelendost (30 dk), Çakır ve
Körküler (40 dk) çeşitlerinde; en geç ise Ağlasun çeşidinde (90 dk) bulunmuştur. Çizelge 2.5.2'de görüldüğü gibi, nohut genotipleri arasında 100 tane ağırlığı ortalamaları bakımından yüksek oranda varyasyonlar belirlenmiş olup, en yüksek 100 tane ağırlığı ortalamaları Kabak, Gelendost ve Yeşilköy genotiplerinde, en düşük 100 tane ağırlığı ortalamaları ise Ağlasun, Ziraat2, Çetince ve Leblebilik nohut genotiplerinde belirlenmiştir. En yüksek kabuk oranı ortalamalarına da Kabak, Bozkır, Gelendost ve Yeşilköy genotipleri sahip olurken, en düşük ortalamalar ise Ziraat2, Leblebilik, Ziraat3 ve Sarı 98 nohut genotiplerinde ölçülmüştür.

Çizelge 3'te gösterildiği gibi, nohut genotipleri arasında su alma kapasiteleri ortalamaları bakımından yüksek oranda varyasyonlar gözlenmiş olup, en yüksek su alma kapasitesi ortalamaları Kabak, Bozkır, Yeşilköy ve Gelendost genotiplerinde görülürken, en düşük su alma kapasitesi ortalamaları ise Ağlasun, Çetince, Ziraat2 ve İspanyol nohut genotiplerinde görülmüştür. Su alma indeksi ortalamaları yönünden ise en yüksek değerler Leblebilik, Ziraat3, Ziraat2 ve Bozkır genotiplerinde; en düşük su alma indeksi değerlerine ise Çetince, Hisar, İspanyol ve Denizli nohut genotipleri sahip olmuştur.

Çizelge 2. Göller yöresi illerinden toplanan bazı nohut genotiplerinde protein oranı (PO), pişme süresi (PS), 100 tane ağırlığı (100TA) ve kabuk oranı (KO) ortalamaları*

Table 2. Crude protein rate (PO), cooking time (PS), 100 grain weight (100TA) and testa rate (KO) averages of some chickpea genotypes collected from the Lake District Provincials

\begin{tabular}{|c|c|c|c|c|}
\hline Çeşitler & $\mathrm{PO}(\%)$ & $P S(d k)$ & 100TA $(\mathrm{g})$ & $\mathrm{KO}(\%)$ \\
\hline Kırmızı yerel & $10.24 \mathrm{k}$ & $80 b$ & $47.61 \mathrm{~cd}$ & $2.01 d$ \\
\hline Ağlasun & $20.63 j$ & $90 a$ & $34.79 \mathrm{k}$ & $1.46 \mathrm{k}$ \\
\hline Çetince & 21.14ij & $70 c$ & $35.44 \mathrm{jk}$ & $1.55 j$ \\
\hline Úzunlu 99 & $25.97 b$ & $65 \mathrm{cde}$ & $39.79 \mathrm{~h}$ & $1.63 \mathrm{gh}$ \\
\hline Çaltı & I- I-81. & 50f-I & $42.15 \mathrm{gh}$ & 1.60hij \\
\hline Ziraat1 & $21.61 \mathrm{~g}-\mathrm{j}$ & $60 c-f$ & $50.47 \mathrm{c}$ & $1.91 \mathrm{e}$ \\
\hline Karamanlı & 22.14e-I & 50f-I & $43.51 \mathrm{efg}$ & $1.91 \mathrm{gh}$ \\
\hline A. Gökdere & $24.59 c$ & 50f-I & $48.08 \mathrm{~cd}$ & $1.89 \mathrm{e}$ \\
\hline Çakır & $20.67 j$ & $40 ı$ & $46.20 \mathrm{de}$ & $1.77 f$ \\
\hline Yarıkkaya & $21.42 \mathrm{~h}$ ij & $45 \mathrm{~h}$ & $43.49 \mathrm{fg}$ & $1.42 \mathrm{k}$ \\
\hline Körküler & $22.24 \mathrm{e}-\mathrm{h}$ & 40ıj & $45.59 \mathrm{def}$ & $1.72 \mathrm{fg}$ \\
\hline Hisar & $22.46 \mathrm{~d}-\mathrm{g}$ & $58 d-g$ & 40.06hı & $1.59 \mathrm{j}$ \\
\hline İspanyol & 21.95f-I & $55 d-h$ & $40.43 \mathrm{~h}$ & $1.55 ı j$ \\
\hline Denizli & ו- ו-99f & $50 f-I$ & $40.43 \mathrm{~h}$ & 1.69fgh \\
\hline Bozkır & $25.86 b$ & $65 \mathrm{~cd}$ & $47.85 \mathrm{~cd}$ & $2.32 \mathrm{~b}$ \\
\hline Gelendost & $21.69 g-j$ & $30 \mathrm{j}$ & $56.34 b$ & $2.11 \mathrm{c}$ \\
\hline Yeşilköy & 22.71def & $60 c-f$ & $54.29 \mathrm{~b}$ & $2.11 \mathrm{c}$ \\
\hline Kabak & 21.33hıj & $65 \mathrm{~cd}$ & $64.99 a$ & $3.07 a$ \\
\hline Sarı 98 & $23.47 d$ & $50 \mathrm{gh}$ & $49.56 c$ & 0.881 \\
\hline Leblebilik & $23.05 \mathrm{de}$ & $55 e-h$ & $38.16 \mathrm{ij}$ & $0.66 \mathrm{~m}$ \\
\hline Ziraat2 & $27.57 a$ & $50 f-I$ & $35.50 \mathrm{k}$ & $0.73 \mathrm{~m}$ \\
\hline Ziraat3 & 21.82f-I & $55 d-h$ & $42.02 \mathrm{gh}$ & $0.74 \mathrm{~m}$ \\
\hline Ortalama & $21.021-1$ & & 44.8 & \\
\hline
\end{tabular}

* Aynı harfle gösterilen ortalamalar arasında farklılık yoktur

*Averages followed by same letter are not different 
Çizelge 3. Göller yöresi illerinden toplanan bazı nohut genotiplerinde su alma kapasitesi (SAK), su alma indeksi (SAi), şişme kapasitesi (ŞK) ve şişme indeksi (Şi) ortalamaları*

Table 3. Capacity of water intake (SAK), water intake index (SAI), swelling capacity (SKK) and swelling index (Şi) averages of some chickpea genotypes collected from the Lake District Provincials

\begin{tabular}{|c|c|c|c|c|}
\hline Çeşitler & SAK & SAI & ŞK & Şi \\
\hline Kırmızı yerel & $0.52 \mathrm{ef}$ & $1.18 \mathrm{I}$ & $0.500 \mathrm{k}$ & $2.390 \mathrm{gh}$ \\
\hline Ağlasun & 0.390 & 1.080 & $0.350 p$ & $2.283 \mathrm{jkl}$ \\
\hline Çetince & $0.41 n$ & $0.70 r$ & $0.253 q$ & $1.847 p$ \\
\hline Uzunlu 99 & $0.45 \mathrm{jkl}$ & $1.10 \mathrm{no}$ & $0.387 n$ & $2.2231 \mathrm{~m}$ \\
\hline Çaltı & $0.49 \mathrm{hl}$ & $1.11 \mathrm{n}$ & $0.477 \mathrm{~lm}$ & $2.390 \mathrm{gh}$ \\
\hline Ziraat1 & $0.63 d$ & $1.14 \mathrm{~m}$ & $0.520 \mathrm{j}$ & $2.257 \mathrm{klm}$ \\
\hline Karamanlı & $0.50 \mathrm{gh}$ & $1.21 \mathrm{k}$ & 0.4801 & $2.423 \mathrm{gh}$ \\
\hline A. Gökdere & $0.53 e$ & $1.34 \mathrm{j}$ & 0.590। & $2.500 f$ \\
\hline Çakır & $0.48 \mathrm{I}$ & 1.45 I & $0.633 \mathrm{~h}$ & $2.793 e$ \\
\hline Yarıkkaya & $0.51 \mathrm{fg}$ & $1.21 \mathrm{k}$ & $0.470 \mathrm{~m}$ & 2.353hıj \\
\hline Körküler & $0.52 \mathrm{efg}$ & ו1.17 & $0.483 \mid$ & $2.340 ı j$ \\
\hline Hisar & $0.44 \mathrm{klm}$ & $1.00 q$ & 0.3630 & 2.0930 \\
\hline İspanyol & $0.43 \mathrm{~m}$ & $1.01 p q$ & $0.380 n$ & 2.130 no \\
\hline Denizli & $0.44 \mathrm{Im}$ & $1.02 p$ & $0.380 n$ & $2.203 \mathrm{~m}$ \\
\hline Bozkır & $0.67 b$ & $2.52 \mathrm{~d}$ & $1.080 \mathrm{e}$ & $3.633 a$ \\
\hline Gelendost & $0.66 \mathrm{bc}$ & $2.16 \mathrm{~g}$ & $1.070 f$ & $3.363 c$ \\
\hline Yeşilköy & $0.66 c$ & $2.21 \mathrm{f}$ & $1.087 e$ & $3.433 b$ \\
\hline Kabak & $0.72 a$ & $1.82 \mathrm{~h}$ & $1.097 \mathrm{~d}$ & $3.210 \mathrm{~d}$ \\
\hline Sarı 98 & $0.53 e$ & $2.49 \mathrm{e}$ & 1.140b & $2.257 \mathrm{~lm}$ \\
\hline Leblebilik & $0.45 \mathrm{jk}$ & $3.46 a$ & $1.153 a$ & $2.443 \mathrm{fg}$ \\
\hline Ziraat2 & $0.42 n$ & $2.83 c$ & $0.937 \mathrm{~g}$ & $2.193 \mathrm{mn}$ \\
\hline Ziraat3 & $0.46 \mathrm{j}$ & $2.93 b$ & $1.117 c$ & 2.333ıjk \\
\hline Ortalama & 0.51 & 1.64 & 0.67 & 2.50 \\
\hline
\end{tabular}

${ }^{*}$ Aynı harfle gösterilen ortalamalar arasında farklılık yoktur.

${ }^{*}$ Averages followed by same letter are not different

Çizelge 4. Göller yöresi illerinden toplanan bazı nohut genotiplerinde tane nem içeriği (\%) ve elek analizi (9, $8,7 \mathrm{~mm}$ elek) ortalamaları*

Table 4. Grain moisture ( $T$ Nemi) and sieve analysis (9, 8, $7 \mathrm{~mm}$ sieves) averages of some chickpea genotypes collected from the Lake District Provincials

\begin{tabular}{lcccc}
\hline Çeşitler & Tane Nemi & $9 \mathrm{~mm}$ & $8 \mathrm{~mm}$ & $7 \mathrm{~mm}$ \\
\hline Kırmızı yerel & $11.07 \mathrm{abc}$ & 28.37 & 66.89 & 4.56 \\
Ağlasun & $7.23 \mathrm{e}-\mathrm{h}$ & 2.53 & 57.02 & 40.45 \\
Çetince & $7.38 \mathrm{e}-\mathrm{h}$ & 11.07 & 67.18 & 20.90 \\
Uzunlu 99 & $11.83 \mathrm{ab}$ & 13.28 & 55.93 & 24.53 \\
Çaltı & $3.88 \mathrm{a}$ & 31.01 & 56.07 & 11.39 \\
Ziraat1 & $10.10 \mathrm{a}-\mathrm{d}$ & 75.80 & 23.85 & 0.00 \\
Karamanlı & $9.33 \mathrm{~b}-\mathrm{g}$ & 26.86 & 64.49 & 9.58 \\
A. Gökdere & $9.03 \mathrm{c}-\mathrm{g}$ & 61.54 & 35.26 & 2.88 \\
Çakır & $6.00 \mathrm{hl}$ & 36.49 & 59.46 & 4.05 \\
Yarıkaya & $11.03 \mathrm{abc}$ & 40.78 & 46.93 & 10.09 \\
Körküler & $10.00 \mathrm{a}-\mathrm{d}$ & 44.21 & 49.70 & 6.10 \\
Hisar & $9.33 \mathrm{~b}-\mathrm{f}$ & 6.61 & 74.76 & 16.30 \\
İspanyol & $7.50 \mathrm{~d}-\mathrm{h}$ & 0.49 & 99.06 & 0.41 \\
Denizli & $8.43 \mathrm{c}-\mathrm{h}$ & 0.68 & 97.99 & 0.47 \\
Bozkır & $10.57 \mathrm{abc}$ & 29.55 & 42.42 & 22.22 \\
Gelendost & $12.27 \mathrm{a}$ & 83.33 & 16.03 & 0.63 \\
Yeşilköy & $9.40 \mathrm{~b}-\mathrm{e}$ & 79.95 & 17.68 & 1.40 \\
Kabak & $6.90 \mathrm{fgh}$ & 98.08 & 1.92 & 0.00 \\
Sarı 98 & $7.67 \mathrm{~d}-\mathrm{h}$ & 85.94 & 14.06 & 0.00 \\
Leblebilik & $12.60 \mathrm{a}$ & 1.81 & 37.71 & 49.50 \\
Ziraat2 & $6.60 \mathrm{ghı}$ & 4.47 & 62.45 & 24.06 \\
Ziraat3 & $9.30 \mathrm{~b}-\mathrm{g}$ & 10.53 & 89.47 & 0.00 \\
\hline Ortalama & 8.97 & 35.15 & 51.65 & 11.34
\end{tabular}

${ }^{*}$ Aynı harfle gösterilen ortalamalar arasında farklılık yoktur

${ }^{*}$ Averages followed by same letter are not different 
Denemede kullanılan nohut genotipleri yönünden en yüksek şişme kapasitesi ortalamaları Leblebilik, Sarı 98, Ziraat3 ve Kabak; en düşük şişme kapasitesi ortalamalarına ise Çetince, Ağlasun ve Hisar nohut genotipleri sahip olmuştur. Şişme indeksi ortalamalarında da önemli varyasyonlar görülmüş, en yüksek şişme indeksi ortalamalarına da Bozkır, Yeşilköy, Gelendost ve Kabak genotipleri sahip olmuştur (Çizelge 3).

Denemeden elde edilen sonuçlar topluca değerlendirildiğinde; ele alınan tüm özelliklerde istatistiki yönden çeşitler arasında önemli varyasyonlar belirlenmiştir. Özellikle bazı yerel populasyonlarda ümitvar sonuçlar elde edilmiştir. Hatta bazı yerel çeşitlerin tescilli çeşitlere göre üstün özelliklere sahip oldukları da gözlenmiştir. Bu farklıııklara birçok etmenin neden olabileceği düşünülmektedir. Çeşitlerin yetiştirildiği yörenin iklim ve toprak özellikleri, genotip etkisi, yetiştirme tekniği uygulamaları bu farklılıklara sebep olabilir. Nitekim, Erskine et al. (1985), mercimek tohumlarının irilik, protein ve pişme kalitesine genetik ve çevresel farklııkların etkileri ile ilgili çalışmalarında, baklagillerin protein miktarı ve kalitesine çeşitten başka toprak tipi, iklim, yetiştirme yeri ve agronomik uygulamaların etkisinin olduğunu; Singh et al. (1986), nohut çeşit, hat ve populasyonuna göre tane su alma oranlarının farklılaştığını, genotipin kendisine has tane karakterlerine sahip olduğunu bildirmişlerdir.

Williams et al. (1986) baklagillerde tohumun su absorbsiyon oranı ile pişme zamanı arasında önemli bir ilişkinin olduğunu, sert tohum kabuğuna sahip olan çeşitler, normal kabuk sertliğine sahip olanlar kadar su çekemeyeceğini, ayrıca sert kabuk oluşumu üzerine yetiştirme ortamı, çevre şartları, hasat sırasında ürünün olgunluk durumu, olgunlaşma periyodu boyunca sıcaklık durumu ve hasat yöntemleri (elle, makineli) gibi faktörlerin etkili olduğunu belirtmişlerdir. Akçin (1988) fasulyede protein oranını \%23.26, yağ oranını \%1.96, selüloz oranını $\% 3.88$, kül oranını $\% 3.66$ ve nem oranını \%11.24 belirlemiş, gübreleme, sulama, iklim ve toprak yapısı gibi etmenlerin fasulyenin ham protein oranı üzerinde etkili olduğunu ifade etmiştir. Köksel ve ark. (1993) çevrenin bazı nohut çeşitleri üzerine etkileri ile ilgili araştırmalarında, çeşit ve çevrenin kuru ağırlık, yas ağırlık, kuru ve yaş hacim, su alma indeksi, su alma kapasitesi ve şişme kapasitesi değerlerini etkilediğini, sadece çevrenin kuru pişme süresi ve protein miktarı üzerinde etkili olduğunu belirtmişlerdir. Atlı ve ark. (1994), yemeklik tane baklagillerde kalite değerlendirmesi konulu çalışmalarında, baklagil kalite kriterleri üzerine çeşit, yetiştirme yeri, toprak ve iklim özellikleri, olgunlaşma durumu, depolama koşulları, tanenin fitik asit oranı, kalsiyum, sodyum, serbest pektin, tane kabuğu kalınlığı, lignin ve alfa-selüloz miktarları gibi birçok faktörün etkili olduğunu bildirmişlerdir.

\section{Sonuç}

Göller Bölgesi ve yakında yer alan illerden (Isparta, Burdur, Denizli, Afyon ve Uşak) toplanan yerel ve ülkemiz tescilli nohut (Cicer arietinum L.) çeşitlerinde yapılan çalışmamızda, bazı teknolojik özellikler ve kalite kriterleri yönünden genotipler arasında çok önemli farklılıklar belirlenmiştir. Yerel populasyonlar arasında teknolojik özellikler bakımından ümitvar genotipler belirlenmiştir. Bazı özellikler yönünden yerel populasyonlar içerisinde ülkemiz tescilli çeşitlerinden daha yüksek değerler içeren bazı genotiplere rastlanılmıştır. Bu genotiplerin özellikle ıslah çalışmalarında kullanılabilme potansiyelinin olduğu söylenebilir. Ancak çeşitlerin performansları yönünden görülen bu varyasyonların nedenlerinin tam olarak ortaya konulması gerekmektedir.

Materyallerin farklı ekolojik koşullardan toplanmış olması ve uygulanan yetiştirme tekniklerinin tam olarak bilinmemesi sonuçların hassasiyetini etkileyebilir. Kesin yargılara varabilmek amacıyla toplanan bu materyallerin aynı ekolojik koşullarda benzer yöntemlerle yetiştirilerek aynı analizlerini yapılması ve denemelerin daha fazla sürede tekrarlanmasına gereksinim vardır.

\section{Kaynaklar}

Akçin A., 1988. Yemeklik Tane Baklagiller. S.Ü. Ziraat Fakültesi, 8-43

Akdağ C., 1996. Yemeklik Tane Baklagiller. Gaziosmanpaşa Üni. Ziraat Fak. Yayınları, s: 9-30

Atlı A., Köksel H. ve Dağ A., 1994. Yemeklik tane baklagillerde kalite değerleri. Gıda Sanayii, 7(3): 44-48

Cengiz B., 2007. Sakarya ve eskişehir lokasyonlarında yetiştirilen bazı kuru fasulye çeşitlerinin kalite özellikleri. Yüksek Lisans Tezi, Namık Kemal Üni. Fen Bilimleri Enstitüsü, Gıda Müh. Anabilim Dalı, $78 \mathrm{~s}$

Ceyhan E., 2004. Effect of Sowing dates on some yield components and yield of dry bean (Phaseolus vulgaris L.) cultivars. Turkish Journal of Field Crops, 9: 87-95 
Ercan R., Köksel H. and Atli A., 1995. Cooking quality and composition of chickpea a grown in Turkey. Gıda Teknoloji Dernegi Yayınları, 20(5): 289-293

Erskine W., Williams P.C. and Nakkoul H., 1985. Genetic and environmental variation in the seed size, protein, yield and cooking quality of lentils. Field Crops Research, 12:153-161

Jood S., Bishnoi S. and Sharma A., 1998. Chemical analysis and physico-chemical properties of chickpea and lentil cultivars. CCS Haryana Agricultural University, Department of Food and Nutrition, Nahrung, 42: 71-74

Karasu A., 1993. Bazı nohut çeşitlerinin agronomik ve teknolojik karakterleri üzerinde bir araştırma (Yüksek Lisans Tezi). Uludağ Üni. Fen Bilimleri Enstitüsü, Tarla Bitkileri Anabilim Dalı, Bursa

Köksel H., Atli A. ve Dağ A., 1993. Çevrenin bazi nohut çeşitlerinin teknolojik özelliklerine etkileri. Tarla Bitkileri Merkez Arastirma Enstitüsü Dergisi Cilt: 2, Sayı: 1, Ankara
Peksen E. ve Artik C., 2005. Antibesinsel maddeler ve yemeklik tane baklagillerin besleyici degerleri. O.M.Ü. Ziraat Fak. Dergisi, 20(2): 110-120

Singh K.B., Williams P.C. and Nakkoul H., 1986. Influence of the winter planting on yield and some quality parameters of kabuli -type chickpeas. Crops Res

Williams P.C., EL-Haramein F.J., Nakkoul H. and Rihavi S., 1986. Crop Quality Evalution Methods and Guide lines. ICARDA, Alepro, Syria, $142 p$

Wiryaman K.G., 1997. Final Raport For Project: UQ21E New Vegetable Protein For Layers. Departman of Animal Production, The University of Queensland Gatton 4345, p:1102 